\title{
Economies of Scale in Chinese Commercial Banking Sector
}

\author{
Jian Yao \\ Martin de Tours School of Management and Economics, Assumption University, 592 \\ Ramkhamkaeng 24 Rd, Hua Mak, Bangkapi, Bangkok, 10240, Thailand
}

Keywords: Economies of Scale; Commercial Banking; SUR

\begin{abstract}
With the development of market economy, finance has become an important part of modern economy. A stable and efficient financial system is an important condition for the healthy and harmonious development of a country's economy. As an important part of the financial system, banks play an important role in social and economic life. This paper used translog cost function to measure the economies of scale among Chinese commercial banking sector with 14 Chinese commercial banks' data during 2001 to 2014. The result indicated that economies of scale widely existing among Chinese commercial banking sector, however, medium commercial banks have stronger economies of scale than large banks and small banks. What's more, this paper also approved previous studies which indicated that technology can help banks' managers to reduce their cost. And those findings of this paper also provided diverse reasonable suggestions for new private banks' development in the future.
\end{abstract}

\section{Introduction}

After Chinese economic reform, Chinese banking industry is experiencing the challenge of change and fierce competition. Chinese Government started to set systematic banking system since 1978 and the first Chinese joint-equity commercial bank, Bank of Communications, was created in 1986, which broken the monopoly of Chinese stated owned commercial bank [1]. After that, Chinese banking industry is rapidly increasing. For example, FUDIAN BANK, the first local stated owned joint equity commercial bank of Yunnan Province, was created in the end of 2007, after 5 years' development, it has owned 112 branches in China. The new change started from the end of July of 2013, the China Banking Regulatory Commission (CBRC) announced that Chinese Government encouraging private capitals to establish private bank in China at their own risk responsibly [2]. Before that, Chinese Government did not allow private capitals to operate commercial bank and operate business of deposit and credit; all of Chinese Commercial Banks are pure state-owned banks or state owned joint-equity commercial banks.

According to Stigler (1958), all business may start from small business. That means Chinese private capitals need to set a new bank from small one [3]. So, it is important to use the economies of scale to help Chinese senior and junior bankers to know how to create an efficient commercial bank in China to face future intense competition, especially to know how to face the competition of Chinese large state-owned banks. The measurement of economies of scale can help banks' 
managers to improve their operational decisions and to access the question whether bank is "the bigger the better" [4]. The measure of economies of scale of Chinese banking industry can help bankers to find the optimum size of a new bank which is efficient and profitable.

At the beginning of November of 2013, China stared a series of economic and financial reform, and China is facing the critical moment of economic transition. According to Zonghua Liu (2004), high efficient Bank can help economic transition countries to pass this critical moment stably [5]. So, it is also significant for Chinese government to know how to monitor the development of private capital in Chinese commercial banking sector. The measurement of economies of scale among Chinese banking sector can help Chinese government control the size of private banks, in order to avoid the problem of "too big to fail".

According to the research of Xuhao Jin (2007), the study of economies of scale in banking industry started from U.S sine 1950s, Alhadaff started to link banks' operational cost with scale economies of bank and then calculated the scale economies of Californian banks [1]. After one decade, Benston and Bell used Cobb-Douglas cost function and found economies of scale exist in banking industry but their work based on loglinear Cobb-Douglas form, then Benston cooperated with Hanweck and Humphrey created a translog cost function to test scale economies of banks and found average cost curve is a U-shape $[1,6]$. After that, translog cost function is considering as one of most appropriate ways to test economies of scale in the world.

The research on economies of scale of Chinese banking sector started since 1990s, which is 30 years late than western countries. Based on the research of Zonghua Liu (2004), the first Chinese academic paper of scale economies of Chinese banking sector was written by Haiyan Luo in 1990, who found Chinese Banking industry has medium scale economies and banking industry's economies of scale is not obvious as manufacturing industry [5]. However, after two decades, Chinese researchers did not get a constant result about the question whether Chinese commercial banking sector has economies of scale. After research, I found variable results were caused by diverse ways of measurement and different principle, and the biggest difference appeared in the ways of measurement of scale economies.

First of all, the first difference appeared in the data gathering, all most of the researcher only used 4 to 10 years' data, and those data come from different period that caused different result. Based on the academic papers of western countries, the most of the data are equal or more than 10 years. Then, the second difference appeared in the ways of measure scale economies. Based on research, there are divers ways, such as survivor technique and cost function, are popular to be used to measure economies of scale of Chinese banking industry. The variables are different even they using same function or technique, so it is very important to find one appropriate way and some variables to measure economies of scale in Chinese commercial banking sector. Thirdly, the literature on scale economy in Chinese commercial banking sector is limited in comparison to that for US banking commercial industry and for Chinese manufacturing industry. In contrast to the literature of economy of scale in US banking commercial industry and Chinese manufacturing industry, the literature of scale economies in Chinese commercial banking sector is normally was considered as less updated. So, it is meaningful to use new data to update the literature.

This paper aims to use new updated data and one of most appropriate ways of measurement to test whether economies of scale existing among the Chinese commercial banking sector or whether the bank is "the bigger the better in China". This study is different from previous studies because it used updated data to measure Chinese commercial banking sector's scale economies, which can be more convincing for bankers and government officers to make decision in the future. 


\section{Literature Review}

The principle of economies of scale was introduced by Smith (1776) in his book. According to Smith (1776), the larger factory can get more profit by lowering cost [7]. After several decades, the theory of scale economies has developed but still has some gap. According to Stigler (1958), the theory of scale economies never achieve scientific prosperity before 1950s, and there are no economies of scale in monopoly industry because there are no competition exist, then he tried to use "survivor technique" to measure the efficiency and scale economies of US steel industry and automobile industry; He classified the companies in an industry by size and calculated the share of industry output coming from each class over time, one company was considered efficient if its total share would increase during a long-term [4]. In the end, he found that the cure of scale economies is a U-shape curve and not a straight line, but he did not follow up on was that cost is one of significant factors which can affect economies of scale.

Now, people normally associated economies of scale with the reducing of average cost and the increasing of output. But many people still confuse about the difference between "economies of scale" and "increasing returns to scale". According to Pindyck and Rubinfeld (2015), economies of scale means "a doubling of output requires less than a doubling of cost" and diseconomies of scale means "when a doubling of output requires more than twice the cost"; but for returns of scale, the cost is consistent even the output is increasing [8]. So, one firm has economies of scale when its increasing rate of output is more than the increasing rate of input, and it has diseconomies of scale when its increasing rate of input more than the increasing rate of output; for the theory of economies of scale, the cost of output is variable, but for the theory of returns to scale, the cost of one firm is fixed during all time. What's more, we can use cost-output elasticity to measure economies of scale, and cost-output elasticity equal to marginal cost divide by average cost; economies of scale exist when firm's cost-output elasticity less than 1 [8].

Just as first part informed, first study about scale economies of banking was written by Alhadaff in 1954, he classified Californian banks by amount of deposit and then tested whether Californian banking industry had scale economies based on the data during 1938-1953; then Hprvitz used Alhadaff's way to find that the average cost did not reduce when the amount of deposit increased from 5 million dollars to 500 million dollars [1]. Then, Benston $(1965,1972)$ and Bell and Murphy (1968) has developed a Cobb-Douglas cost functions to test scale economies among banking industry and found that economies of scale existed among banking industry [9,10,11]; According to the average scale elasticity was between $93 \%$ to $95 \%$, that means the cost only increased $9.3 \%$ to 9.5\% when output increased 10\%. But Cobb-Douglas cost function has its own restriction and it ignored cost complementarities. After one decade, Benston, Hanweck and Humphrey (1982) developed a translog cost function to test economies of scale among banking industry, they found there was a U-shape average cost curve for small bank and there was diseconomy of scale for large bank which is consistent as Stigler's result [12].

So far, the literature on economies of scale in western countries has well developed. In America, Mitchell and Onvural (1996) found translog cost function can be well adapted to be applied to capture scale economies of commercial banking sector, and large banks of America had economies of scale with cost efficient [13]. Then, McNulty (2000) used both Cobb-Douglas and translog functions to estimate scale economies of American banking industry. According to his paper, the output of commercial bank was defined as average total assets and cost was defined as operating cost, and he found American banking industry exist economies of scale and the optimum commercial bank size in the \$3 to 5 billion-dollar range. In Australia, Walker (1998) also used translog cost function to estimate scale economies among Australian commercial banking sector, he defined “commercial loans", "housing loans" and "investments” as output, "operating and interest 
expense" as total cost and "cost of labor and deposits (such as interest)" as inputs; then he found economies existed among Australian banking industry and bank can improve their cost efficiency through improving technology and merging [14]. In England, Simper (1999) has estimated that economies of scale existed among Italian saving bank industry and confirmed that U-Shape cost cure existed in European institutions. In Canada, Allen and Liu (2005) used deposits, labor and capital as input and used loans as output to estimate the economies of scale and relative efficiency of Canadian banks based on flexible translog cost function, they found Canadian banks had economies of scale with at least $6 \%$ cost saving and technology and regulatory changes has significant impact on bank's cost efficiency [4].

Compare with western countries' literature, the literature on economies of scale in Chinese banking is limited and less updated. Liu and Luo (1990) first studied economies of scale among Chines banking industry in China, they found Chinese banking industry has median scale economies, but all of Chinese commercial banks were large too much and have stayed at the stage of diseconomies of scale area [15]. Xu, Zheng and Qi (2002) first applied translog cost function to measure economies of scale among Chinese commercial banking sector during 1994 to 2000, they found four largest Chinese state-owned commercial banks had diseconomies of scale and other Chinese joint-equity commercial banks had economies of scale during 1994 to 2000 [16]. Later, Yu and Gao (2003) first used survivor technique combined with translog cost function to find economies of scale exist among Chines commercial banking industry, but all Chinese banks stayed at the stage of diseconomies of scale [17].

Based on research, there are diverse factors may affect the economies of scale among banking industry, which are technology, regulatory changes, internal operational and managerial efficiency and market structure $[1,4,11,14]$ and translog cost function can be appropriately used to measure economies of scale among commercial banking sector. The table 1 briefly summarized the contents of each literature. Based on that, we can notice that translog function was generally used by many countries' researchers, and labor cost, capital cost and interest cost were commonly used as input, the total capital or deposit can be used as input.

In the next section, I used translog cost functions which are applied by earlier studies, but data are slightly different with previous studies, the data is gathered from longer period which can avoid the issue which variable result cause by different period data.

\section{Methodology and Data}

\subsection{Methodology}

A mathematical modelling is used to calculate the result. The input and output of bank in competitive market can be represented as the following:

$$
\mathrm{C}(\mathrm{Y}, \mathrm{W})=\min \{\mathrm{WX}: \mathrm{F}(\mathrm{Y}, \mathrm{X})=0, \mathrm{Y} \geq 0, \mathrm{X} \geq 0\}
$$

Where $\mathrm{X}$ is input of a non-negative vector, $\mathrm{Y}$ is output of a non-negative vector, $\mathrm{W}$ is input price of a non-negative vector for input X. C (Y, W) represents a long-term cost function for a bank which has multiple products in a competitive market and production technology was represented by $\mathrm{F}(\mathrm{Y}, \mathrm{X})$. The bank is assumed can achieve minimum cost $\sum W_{j} X_{j}$ when the restriction of its production technology function $\mathrm{F}(\mathrm{Y}, \mathrm{X})=0$. What's more, the cost function $\mathrm{C}$ is non-decreasing, concave and continuous for vector $\mathrm{W}$. Above condition and restriction can make sure cost function can accurately reflect bank's production process, and that means at a specific point we can get minimum cost. 


\subsection{Function Form}

Considering the availability of data, there is 1 output and 3 inputs are going to be sued to estimate bank's cost function by translog cost function. Translog cost function is considered as one of most appropriate way to measure economies of scale in each countries' commercial banking sector $[4,13,14]$. In this paper, the following translog cost function is using to calculate economies of scale with technology improving variable $\mathrm{T}$ :

Formula 1:

$$
\begin{aligned}
& \ln C=\alpha_{0}+\sum \alpha_{q} \ln Q+\sum \beta_{l} \ln W+\sum \beta_{k} \ln R+\sum \beta_{i} \ln i \\
& +1 / 2 \sum \sum \alpha_{q q}(\ln Q)^{2}+1 / 2 \sum \sum \beta_{l l}(\ln W)^{2}+1 / 2 \sum \sum \beta_{k k}(\ln R)^{2} \\
& +\sum \sum \beta_{l k} \ln W \ln R+\sum \sum \phi_{l q} \ln W \ln Q+\sum \sum \phi_{i q} \ln I \ln Q+\delta_{t} T \\
& +1 / 2 \delta_{t} T^{2}+\delta_{q t} T \ln Q+\delta_{l t} L \ln W+\delta_{k t} T \ln R+\delta_{i t} T \ln I
\end{aligned}
$$

Where $\mathrm{C}$ is long-term total cost with input W (labor cost), input R (cost of capital) and input I (interest cost). What's more, Q represents the output of bank (total capital). T indicates the variable of technology improving and it is a dummy variable. Based on above equation, we can get the value of each coefficient.

According to Zigova (2000), this function need to satisfy the restriction and Symmetry with the following [18]:

$$
\begin{aligned}
& \beta_{L}+\beta_{K}+\beta_{I}=1 ; \beta_{L K}+\beta_{L L}+\beta_{L I}=0 ; \beta_{K K}+\beta_{L K}+\beta_{I K}=0 ; \beta_{I I}+\beta_{L I}+\beta_{I K} \\
& \quad=0 ; \phi_{L Q}+\phi_{K Q}+\phi_{I Q}=0 ; \delta_{L T}+\delta_{K T}+\delta_{I T}=0
\end{aligned}
$$

Then, we can define economies SE with the following:

$$
S E=\partial \ln C / \partial \ln Q=\alpha_{Q}+\alpha_{Q Q} \ln Q+\varphi_{L Q} \ln W+\varphi_{K Q} \ln R+\varphi_{I Q} \ln I+\delta_{Q T} T
$$

Based on above function, if $\mathrm{SE}<1$, the bank has economies of scale, that means the increasing rate of total cost less than $1 \%$ when this bank's total capacity (output) increasing $1 \%$. If $\mathrm{SE}=1$, that means the bank has neither economies of scale nor diseconomies of scale, the change of total cost same as the change of total capacity (output). If $\mathrm{SE}>1$, that means the bank has diseconomies of scale, the increasing rate of total cost of this bank is higher than its total capacity (output) increasing rate.

What's more, the following function shows how technology improving affects the total cost:

$$
T P=\partial \ln C / T=\delta_{T}+\delta_{Q T} \ln Q+\delta_{L T} \ln W+\delta_{K T} \ln R+\delta_{I T} \ln I+\delta_{T T} T
$$

In banking industry, technology is widely using in each department, so it is significantly to know the impact of technology in banking sector. If TP $<0$, that means the improving of technology in banking sector can reduce cost, if $\mathrm{TP}=0$, that mean no change, if $\mathrm{TP}>0$, that means the improving of technology will increase the total cost of bank.

\subsection{Data}

The “Almanac of China's Finance and Banking” was the major data source((see table 1)). The total cost was defined as the sum of variable cost (operation cost, interest cost and other cost). Bank output was defined as the total capital of that bank. The inputs of Banks were divided to three parts, which are capital cost, labor cost and interest cost. Capital cost was defined as the annual fixed cost which occurred for get output (capital), the input cost for labor was recorded based on Banks' labor 
salary, bonus and other welfare. Alternative balance sheets and income statements were measured and got similar result.

Table 1: The List of Chinese Banks and Abbreviation

\begin{tabular}{|c|c|}
\hline $\begin{array}{c}\text { China Construction Bank (CCB) } \\
\text { Industrial and Commercial Bank of China } \\
\text { (ICBC) }\end{array}$ & $\begin{array}{c}\text { Agricultural Bank of China (ABC) } \\
\text { Shanghai Pudong Development Bank } \\
\text { (SPDB) }\end{array}$ \\
\hline China Minsheng Bank (CMBC) & China Merchants Bank Ltd (CMB) \\
\hline Industrial Bank Co., Ltd (CIB) & Bank of Communications (BCM) \\
\hline China Everbright Bank (CEB) & China CITIC Bank (CITICB) \\
\hline Guangdong Development Bank (GDB) & Bank of China (BOC) \\
\hline Shenzhen Development Bank (SDB) & HUAXIA BANK (HUAXIAB) \\
\hline
\end{tabular}

\section{Empirical Results}

To estimate the translog cost function which show above, a panel data set for the years 2001 to 2014 was collected from the 14 largest commercial banks in China and 154 observations because of the data availability, and those data are estimated by Seemingly Unrelated Regression (SUR). Only 14 largest banks' data was chosen because of data availability and those small banks' data are not available. The estimated results as following, table 2.

Table 2 The Value of Variables of Regression Result

\begin{tabular}{|c|c|c|c|}
\hline Variable & Coefficient & Variable & Coefficient \\
\hline$\alpha_{0}$ & $-16.245(12.59)$ & $\phi_{K Q}$ & $0.109(0.25)$ \\
\hline$\alpha_{Q}$ & $3.635(1.36)^{* *}$ & $\phi_{I Q}$ & $-0.011(0.13)$ \\
\hline$\beta_{L}$ & $-0.684(2.55)$ & $\alpha_{d}$ & $-0.080(0.11)$ \\
\hline$\beta_{K}$ & $-0.818(1.81)$ & $\alpha_{Q}$ & $0.190(0.113)$ \\
\hline$\beta_{I}$ & $0.252(2.29)$ & $\delta_{T}$ & $0.087(0.458)$ \\
\hline$\alpha_{Q Q}$ & $-0.264(0.07)^{* * *}$ & $\delta_{I T}$ & $0.000(0.014)$ \\
\hline$\beta_{L L}$ & $0.086(0.18)$ & $\delta_{Q T}$ & $-0.023(0.024)$ \\
\hline$\beta_{K T}$ & $-0.053(0.13)$ & $\delta_{L T}$ & $0.005(0.078)$ \\
\hline$\beta_{I T}$ & $0.127(0.13)$ & $\delta_{K T}$ & $0.028(0.045)$ \\
\hline$\beta_{L K}$ & $-0.459(0.39)$ & $\delta_{I T}$ & $-0.050(0.04)$ \\
\hline$\phi_{L Q}$ & $0.195(0.24)$ & & -0.398 \\
\hline ICBC--C & 0.900 & SPDB--C & -0.446 \\
\hline CCB--C & 0.790 & CIB--C & -0.329 \\
\hline BOC--C & 0.531 & CMBC--C & -0.358 \\
\hline ABC--C & 1.008 & CEB--C & -0.314 \\
\hline BCM--C & -0.039 & SDB--C & -0.393 \\
\hline CMB--C & -0.351 & HUAXIAB--C & -0.270 \\
\hline CITICB--C & -0.330 & GDB--C & \\
\hline R-squared & 0.976 & & \\
\hline
\end{tabular}

Note: The value in bracket is Std. Error, $* *$ is $5 \%$ significant, $* * *$ is $1 \%$ significant.

After using Seemingly Unrelated Regression (SUR) to measure the formula 1 (based on 5\% significance level), table 3 was processed and showed. All of the data are significant, and Adjusted $\mathrm{R}$-squared is 0.969 . The coefficient of each variable was showed in above, which indicated the 
relationship between total cost and indicators (input, output and dummy variable Technology). Then, based on each coefficient, I processed formula 2 and formula 3 to get table 4 and table 6 for each banks from 2001 to 2014.

Table 3 represents the SE value of 14 sample's banks, and the estimated SE averages of all years from 2001 to 2014 are less than 1 in all cases. That means economies of scale existing among Chinese commercial banking sector widely. Table 5 represents the SE value of 14 sample's banks witch classified by total capital, the banks was divided to three groups. Large banks means 4 largest state-owned banks whose total capital more than 10 Trillion RMB, and medium banks and small banks means those banks whose total capital is between 2 to 5 trillion RMB and less than 2 trillion RMB. The estimated SE averages of all type banks of all years from 2001 to 2014 are less than 1, but large banks' SE are obviously higher than medium banks and small banks, that means large banks are less efficient than medium and small banks even all Chinese commercial banks stayed at the stage of economies of scale.

Table 3 The SE value of the sample's banks

\begin{tabular}{|c|c|c|c|c|c|c|c|c|c|c|c|c|c|c|c|}
\hline \multirow[t]{2}{*}{$\begin{array}{l}\text { \% of } \\
\text { Capit } \\
\text { al }\end{array}$} & \multicolumn{4}{|c|}{$\begin{array}{c}\text { More than } 10 \text { Trillion RMB (Large } \\
\text { Bank) } \\
10 \%-15 \%\end{array}$} & \multicolumn{6}{|c|}{$\begin{array}{l}2 \text { to } 5 \text { Trillion RMB (Medium Bank) } \\
\qquad 2 \%-5 \%\end{array}$} & \multicolumn{4}{|c|}{$\begin{array}{c}\text { Less than } 2 \text { Trillion RMB (Small } \\
\text { Bank) } \\
\text { Less than } 2 \%\end{array}$} & \multirow[b]{2}{*}{ Average } \\
\hline & ICBC & CCB & BOC & $\mathrm{ABC}$ & BCM & CMB & СІTICВ & SPDB & CIB & СMBC & CEB & SDB & $\begin{array}{c}\text { HUAX } \\
\text { IAB }\end{array}$ & GDB & \\
\hline 2001 & 0.48 & 0.39 & 0.37 & 0.21 & 0.06 & 0.33 & 0.20 & 0.45 & 0.33 & 0.43 & 0.29 & 0.59 & 0.41 & 0.46 & 0.36 \\
\hline 2002 & 0.53 & 0.43 & 0.41 & 0.29 & 0.03 & 0.19 & 0.20 & 0.24 & 0.20 & 0.21 & 0.18 & 0.48 & 0.37 & 0.40 & 0.30 \\
\hline 2003 & 0.56 & 0.37 & 0.43 & 0.36 & 0.05 & 0.07 & 0.01 & 0.07 & 0.21 & 0.12 & 0.19 & 0.39 & 0.27 & 0.21 & 0.24 \\
\hline 2004 & 0.56 & 0.35 & 0.43 & 0.36 & 0.02 & 0.04 & 0.13 & 0.04 & 0.11 & 0.08 & 0.20 & 0.39 & 0.23 & 0.17 & 0.22 \\
\hline 2005 & 0.51 & 0.43 & 0.48 & 0.45 & 0.11 & 0.04 & 0.14 & 0.01 & 0.01 & 0.02 & 0.11 & 0.29 & 0.20 & 0.18 & 0.21 \\
\hline 2006 & 0.57 & 0.54 & 0.44 & 0.46 & 0.14 & 0.05 & 0.06 & 0.01 & 0.37 & 0.04 & 0.05 & 0.18 & 0.08 & 0.17 & 0.23 \\
\hline 2007 & 0.59 & 0.55 & 1.06 & 0.50 & 0.27 & 0.12 & 0.05 & 0.09 & 0.31 & 0.00 & 0.00 & 0.14 & 0.01 & 0.17 & 0.28 \\
\hline 2008 & 0.63 & 0.62 & 0.50 & 0.44 & 0.24 & 0.14 & 0.09 & 0.20 & 0.04 & 0.01 & 0.03 & 0.04 & 0.08 & 0.22 & 0.24 \\
\hline 2009 & 0.75 & 0.72 & 0.65 & 0.57 & 0.36 & 0.27 & 0.26 & 0.29 & 0.21 & 0.15 & 0.18 & 0.05 & 0.02 & 0.05 & 0.32 \\
\hline 2010 & 0.78 & 0.75 & 0.70 & 0.63 & 0.44 & 0.29 & 0.33 & 0.28 & 0.30 & 0.24 & 0.18 & 0.10 & 0.10 & 0.01 & 0.37 \\
\hline 2014 & 0.79 & 0.76 & 0.72 & 0.63 & 0.50 & 0.32 & 0.15 & 0.42 & 0.34 & 0.26 & 0.23 & 0.23 & 0.10 & 0.03 & 0.39 \\
\hline
\end{tabular}

Note: Calculated by EViews, keep two decimal places.

Table 4 The SE value of the sample’s banks witch classified by total capital

\begin{tabular}{|c|c|c|c|}
\hline & Large Banks & Medium Banks & Small Banks \\
\hline 2001 & 0.3614 & 0.302 & 0.4376 \\
\hline 2002 & 0.4149 & 0.1767 & 0.3565 \\
\hline 2003 & 0.4308 & 0.0912 & 0.2658 \\
\hline 2004 & 0.4253 & 0.0712 & 0.2488 \\
\hline 2005 & 0.4672 & 0.0552 & 0.1922 \\
\hline 2006 & 0.5033 & 0.1129 & 0.1184 \\
\hline 2007 & 0.6777 & 0.1406 & 0.0801 \\
\hline 2008 & 0.551 & 0.1207 & 0.0932 \\
\hline 2009 & 0.6748 & 0.256 & 0.0735 \\
\hline 2010 & 0.7137 & 0.3129 & 0.0977 \\
\hline 2014 & 0.7267 & 0.3329 & 0.1477 \\
\hline Average & 0.5406 & 0.1793 & 0.192 \\
\hline
\end{tabular}


This result is different as previous studies in China. For example, Zheng and Qi (2002) and Jin (2007) used translog cost function to found large Chinese state-owned commercial banks had diseconomies of scale and other Chinese joint-equity commercial banks had economies of scale [1], Yu and Gao (2003) found all Chinese banks stayed at the stage of diseconomies of scale [17], and Liu (2004) found large banks had economies of scale but medium and small banks had diseconomies of scale when he used translog cost function to estimate those data [15]. But according to table 5, the curve of the SE value of the sample's banks witch classified by total capital is a U-shape curve, that means medium banks are more efficient than small banks and large banks, the result is consistent with previous studies $[1,4,15]$.

According to Liu (2004) and Jin (2007), Chinese commercial banks has diseconomies of scale because of bad loans caused high cost $[1,5]$. But this situation has changed after economies crisis. In today's Chinese banking sector, the commercial banks became more cautious than before during investment after global economic crisis, and the higher demand of cash making commercial banks can select more efficient projects to invest, that also improved by Pride et al (2012). The result is different with previous research, but more reasonable [19].

Table 5 The TP value of the sample's banks

\begin{tabular}{|c|c|c|c|c|c|c|c|c|c|c|c|c|c|c|c|}
\hline \multirow[t]{2}{*}{$\begin{array}{l}\% \text { of } \\
\text { Capital }\end{array}$} & \multicolumn{4}{|c|}{$\begin{array}{c}\text { More than } 10 \text { Trillion RMB (Large } \\
\text { Bank) } \\
10 \%-15 \%\end{array}$} & \multicolumn{6}{|c|}{$\begin{array}{l}2 \text { to } 5 \text { Trillion RMB (Medium Bank) } \\
\qquad 2 \%-5 \%\end{array}$} & \multicolumn{4}{|c|}{$\begin{array}{c}\text { Less than } 2 \text { Trillion RMB (Small Bank) } \\
\text { Less than } 2 \%\end{array}$} & \multirow[b]{2}{*}{ Average } \\
\hline & ICBC & CCB & BOC & $\mathrm{ABC}$ & BCM & CMB & CITICB & SPDB & CIB & CMBC & CEB & SDB & $\begin{array}{c}\text { HUAXI } \\
\text { AB }\end{array}$ & GDB & \\
\hline 2001 & -0.1 & 0.05 & 0.09 & 0.07 & -0.05 & -0.01 & -0.02 & 0 & 0.01 & 0 & -0.02 & 0.01 & 0.01 & -0.01 & -0.03 \\
\hline 2002 & -0.09 & 0.04 & 0.07 & 0.06 & -0.04 & -0.01 & -0.01 & -0.01 & 0.02 & -0.02 & -0.02 & 0.01 & 0 & -0.01 & -0.02 \\
\hline 2003 & -0.08 & 0.06 & 0.06 & 0.06 & -0.03 & -0.02 & -0.02 & -0.02 & 0.02 & -0.03 & -0.03 & 0 & 0.01 & -0.02 & -0.03 \\
\hline 2004 & -0.08 & 0.08 & 0.07 & 0.07 & -0.03 & -0.03 & -0.03 & -0.03 & 0.04 & -0.04 & -0.04 & -0.01 & 0.01 & -0.01 & -0.04 \\
\hline 2005 & -0.07 & 0.09 & 0.08 & 0.08 & -0.05 & -0.05 & -0.04 & -0.05 & 0.06 & -0.05 & -0.06 & -0.02 & 0.03 & -0.04 & -0.05 \\
\hline 2006 & -0.11 & 0.1 & 0.1 & 0.09 & -0.09 & -0.07 & -0.06 & -0.06 & 0.01 & -0.07 & -0.08 & -0.08 & 0.06 & -0.04 & -0.07 \\
\hline 2007 & -0.12 & 0.11 & 0.16 & 0.11 & -0.06 & -0.08 & -0.07 & -0.08 & 0.01 & -0.09 & -0.09 & -0.09 & 0.08 & 0.06 & -0.08 \\
\hline 2008 & -0.13 & 0.12 & 0.12 & 0.1 & -0.1 & -0.09 & -0.09 & -0.1 & 0.12 & -0.11 & -0.09 & -0.11 & 0.11 & -0.09 & -0.11 \\
\hline 2009 & -0.13 & 0.12 & 0.11 & 0.1 & -0.1 & -0.09 & -0.08 & -0.11 & 0.11 & -0.09 & -0.08 & -0.09 & 0.1 & -0.07 & -0.1 \\
\hline 2010 & -0.12 & 0.12 & 0.12 & 0.1 & -0.12 & -0.09 & -0.09 & -0.12 & 0.16 & -0.1 & -0.09 & -0.09 & 0.11 & -0.08 & -0.11 \\
\hline 2014 & -0.14 & 0.13 & 0.14 & 0.12 & -0.14 & -0.11 & -0.06 & -0.14 & 0.15 & -0.13 & -0.11 & -0.13 & 0.12 & -0.1 & -0.12 \\
\hline
\end{tabular}

Note: Calculated by EViews, keep two decimal places.

Table 6 The TP value of the sample’s banks witch classified by total capital

\begin{tabular}{|c|c|c|c|}
\hline & Large Banks & Medium Banks & Small Banks \\
\hline 2001 & -0.0754 & -0.0122 & -0.0009 \\
\hline 2002 & -0.065 & -0.011 & -0.0052 \\
\hline 2003 & -0.0668 & -0.0229 & -0.0163 \\
\hline 2004 & -0.0739 & -0.0334 & -0.0171 \\
\hline 2005 & -0.0808 & -0.0485 & -0.0369 \\
\hline 2006 & -0.1012 & -0.0565 & -0.0648 \\
\hline 2007 & -0.1243 & -0.066 & -0.0496 \\
\hline 2008 & -0.1203 & -0.1019 & -0.1 \\
\hline 2009 & -0.115 & -0.0966 & -0.085 \\
\hline 2010 & -0.1143 & -0.1115 & -0.0917 \\
\hline 2014 & -0.1298 & -0.121 & -0.1149 \\
\hline
\end{tabular}


Table 5 represents the TP value of 14 sample's banks, and the estimated TP averages of all years from 2001 to 2014 are less than 0 in all cases. That means technology improving can reduce Chinese commercial banking sector's cost. Table 7 represents the TP value of 14 sample's banks witch classified by total capital, the banks was divided to three groups. Large banks mean 4 largest state-owned banks whose total capital more than 10 Trillion RMB, and medium banks and small banks means those banks whose total capital is between 2 to 5 trillion RMB and less than 2 trillion RMB. The estimated TP averages of all type banks of all years from 2001 to 2014 are less than 0, but large banks' TP are obviously less than medium banks and small banks, that means large banks can get more benefits from technology improving than medium and small banks even all Chinese commercial banks can get benefit from technology improving, and this result is consistent with previous studies.

Three implications follow from above results. First, for private capitals, blindly investment is risky, to create one medium bank which total capital is between 2 to 5 trillion RMB is more efficient than other size banks, and private capitals can reduce bank's cost through technology improving. Secondly, for Chinese government, seriously control the size of private banks can help those new private banks to be more efficient and can pass this critical economic transition moment to avoid the problems of "too big to fail", so Chinese government need to make sure the total capital of new private banks should not be more than 5 trillion RMB. The last but not the least, Chinese large commercial banks is becoming less and less efficient, for large Chinese banks' manager, the investment in technology is necessary which can help large banks to reduce cost and be more efficient.

For future research, more variables, such as loan and deposit, can be added as input and output. Then, more banks' data can be added if more data are available. The last but not the least, production cost also can be used for bank to test the economies of scale, then comparing them to find a new way making commercial bank be more efficient.

\section{Conclusion}

This paper contributed new evidence to the search, found cost translog function can be well applied in Chinese commercial banking sector with 14 banks' data during 2001 to 2014. The result indicated that economies of scale widely existing among Chinese commercial banking sector, however, medium commercial banks have stronger economies of scale than large banks and small banks. What's more, this paper also approved previous studies which indicated that technology can help banks' managers to reduce their cost.

To be specific, if all Chinese commercial banks' total capital increase 1 RMB, large banks' total cost will increase 0.5 RMB, but for small commercial banks and medium banks, their cost will increase only around 2 RMB. However, this paper also found Chinese commercial banks can get more benefit than medium banks and small banks when they invest money in technology development. In the end, this paper also suggests that Chinese commercial banks managers, private capital and Chinese government both need to control the size of new private banks, making sure those new banks can be operated efficiently in China.

\section{References}

[1] J., Xuhao, The Empirical Study of Scale Economies and Scope Economies of Chinese Banking Industry, Chongqing University, (2007): 36-48

[2] Information on http://www.chinascopefinancial.com/en/news/post/27532.html

[3] Stigler, George J. The economies of scale. The Journal of Law and Economics 1 (1958): 54-71.

[4] Allen, Jason, and Ying Liu. Efficiency and economies of scale of large Canadian banks. Canadian Journal of Economics/Revue canadienne d'économique. 40.1 (2007): 225-244. 
[5] L., Zonghua, The Study of Scale Economies and Scope Economies in Chinese Banking Industry, Fudan University, (2004): 51-63

[6] Van Rooij, M. C. J. Bank mergers, banking efficiency, and economies of scale and scope: a review of the empirical literature. No. 511. Netherlands Central Bank, Research Department, 1997.

[7] Smith, Adam. The wealth of nations [1776]. (1937).

[8] Pindyck, R. S., and D. L. Rubinfeld. Microeconomics. Pearson. (2015).

[9] Benston, George J. Branch banking and economies of scale. The Journal of Finance. 20.2 (1965): 312-331.

[10] Benston, George J. Economies of scale of financial institutions. Journal of Money, Credit and Banking 4.2 (1972): 312-341.

[11] Bell, Frederick W., and Neil B. Murphy. Costs in commercial banking: A quantitative analysis of bank behavior and its relation to bank regulation. Vol. 41. Federal Reserve Bank of Boston, 1968.

[12] Benston, George J., Gerald A. Hanweck, and David B. Humphrey. Scale economies in banking: A restructuring and reassessment. Journal of money, credit and banking 14.4 (1982): 435-456.

[13] Mitchell, Karlyn, and Nur M. Onvural. Economies of scale and scope at large commercial banks: Evidence from the Fourier flexible functional form. Journal of Money, Credit and Banking28.2 (1996): 178-199.

[14] Walker, Greg. Economies of scale in Australian banks 1978-1990. Australian Economic Papers 37.1 (1998): 71-87.

[15] L., Kaiyan and L., Haiyan, (1990), Economy of scale, economy of scope and cost management of commercial banks, Modern Economic Science, 4, 1990

[16] Xu, Xiaofei, Zheng, Guitin, and Qi, Shutian, The thinking of cost function-theoretical study and empirical analysis, Forecasting, Issue 1, (2002):32-41

[17] Yu, Chunliang and Gao, Bo, Chinese banking industry scale economies and relative industry policy, China Industrial Economics, Issue 3, (2003):81-92

[18] Zigova, Katarina, Econometri Models of Producer Behaviour: Master Thesis, Comenius University, Bratislava 2000

[19] Pride, William M., Robert J. Hughes, and Jack R. Kapoor. Foundations of business. Cengage Learning, 2014. 